\title{
Yield Losses Associated with Clinical Mastitis Occurring in Different Weeks of Lactation
}

\author{
C. Hagnestam, ${ }^{* 1}$ U. Emanuelson, $\dagger$ and B. Berglund ${ }^{*}$ \\ ${ }^{*}$ Department of Animal Breeding and Genetics, Swedish University of Agricultural Sciences, P.O. Box 7023, SE-750 07 Uppsala, Sweden \\ †Department of Clinical Sciences, Swedish University of Agricultural Sciences, P.O. Box 7054, SE-750 07 Uppsala, Sweden
}

\begin{abstract}
The effects of the first lactational incidence of clinical mastitis (CM) on milk, fat, and protein production were studied in the Swedish Red and Swedish Holstein breeds. The data consisted of 38,535 weekly production records from 1,192 lactations (506 cows), sampled from 1987 to 2004 in one of the university's research herds. Daily yields were analyzed using a repeated-measures mixed model with an interaction between mastitis index and lactational stage, breed, parity, reproductive status, year-season of calving, and various indices for other disorders as independent variables. The indices were used to distinguish between cows with and without the studied diagnoses, as well as to indicate time (test day) in relation to day of diagnosis. Inclusion of the interaction made it possible to study the effects of CM occurring in different weeks of lactation. Primiparous and multiparous cows were analyzed separately, and the yields of nonmastitic cows were used as a reference for the production level in healthy cows. Lactational (305-d) yield losses were extrapolated from the daily estimates. High milk yield was predisposing to CM. Daily milk yield started to decline 2 to 4 wk before diagnosis. On the day of clinical onset, the milk yield of mastitic cows was reduced by 1 to $8 \mathrm{~kg}$. After a case of CM, milk yield was suppressed throughout lactation. The magnitude of the yield losses was determined by the week of lactation at clinical onset. The greatest losses occurred when primiparous cows developed CM in wk 6, whereas multiparous cows experienced the greatest losses when diseased in wk 3 . The 305-d milk, fat, and protein production in mastitic primiparous cows were reduced by 0 to 9,0 to 8 , and 0 to $7 \%$, respectively. The corresponding reductions in mastitic multiparous cows were 0 to 11,0 to 12 , and 0 to $11 \%$, respectively.
\end{abstract}

Key words: dairy cow, clinical mastitis, yield loss

Received September 11, 2006.

Accepted December 21, 2006.

${ }^{1}$ Corresponding author: christel.hagnestam@hgen.slu.se

\section{INTRODUCTION}

Information about the total cost of a case of clinical mastitis (CM) is crucial for evaluating the economic viability of different preventative measures and for supporting decision-making regarding their implementation. Costs due to CM arise from treatment, reduced milk production, increased risk of culling, and increased risk of subsequent diseases. The main component of the financial loss is reduced production levels in affected cows (Degraves and Fetrow, 1993; Hortet and Seegers, 1998). Thus, the cost of a case of CM will largely depend on the extent of yield losses.

There are numerous studies on the effects of CM on milk production. Yield losses have been studied on a short-term basis (in the weeks before and after clinical onset) as well as with respect to lactational level (mostly 305-d lactations). It is important to analyze short-term losses so that the effects of CM can be assessed accurately. A temporary drop in production associated with a higher yield level before or after the disease might mask the true effects of disease on the 305-d yield (Østergaard and Gröhn, 1999). Furthermore, to make correct management decisions it is essential to know the patterns of short-term loss associated with CM. When deciding whether to cull a cow experiencing reduced production due to CM, it is necessary to know whether she is most likely to regain her premastitic production level, whether she will remain at her current yield, or whether her milk production will become even more reduced (Bartlett et al., 1991).

In a review by Hortet and Seegers (1998), the estimated lactational milk loss was found to vary between 0 and $9.5 \%$ across parities. Management, breed, and yield level, as well as the analytical method used, differed between studies and can be assumed to have influenced the results. Analyses of production losses due to $\mathrm{CM}$ are thus situation-specific and should be conducted on the breed and in the environment of interest to ensure that relevant estimates are obtained.

It is preferable to analyze repeated measures of milk yield within lactation instead of a summary measure of 305-d milk yield (Gröhn et al., 1999). Monthly data 
are not relevant for the assessment of short-term losses or lactational losses when CM occurs in early lactation (Hortet and Seegers, 1998). Therefore, it is recommended that weekly production records should be used for studies of the effects of CM on milk yield.

The extent of the short-term losses, as well as the magnitude of the 305-d losses, has been shown to vary according to when in lactation the cow is diseased (Lucey and Rowlands, 1984; Lucey et al., 1986; RajalaSchultz et al., 1999). To achieve accurate estimates the timing of the disease event must therefore be taken into account. Furthermore, daily yields need to be related to the day of testing with respect to calving as well as to diagnosis.

So far, studies have investigated the effects of CM on milk yield when the disease has occurred in rather crude periods of lactation. No quantification of the losses associated with CM in the different weeks of lactation has been conducted. The aim of this study was to estimate the short-term and long-term production losses associated with $\mathrm{CM}$, taking into consideration the interaction between DIM and day relative to diagnosis for test days.

\section{MATERIALS AND METHODS}

Weekly production records from 1,192 lactations, comprising 38,535 test-day yields collected over $16.5 \mathrm{yr}$ were analyzed to estimate the short-term and 305-d milk, fat, and protein losses associated with CM.

\section{Animals and Management}

Production records were collected between September 1987 and April 2004 at the research farm of the Department of Animal Breeding and Genetics, Swedish University of Agricultural Sciences. Detailed information on disease occurrences, calvings, reproductive status, and culling was available. Test-day records from 307 Swedish Red (SR) and 199 Swedish Holstein (SH) cows of parity 1 to 10 were used in the study. In 2004, the average production of the SR cows in the herd was $8,921 \mathrm{~kg}$ of milk, $387 \mathrm{~kg}$ of fat, and $315 \mathrm{~kg}$ of protein. Corresponding yields of SH cows were 10,626, 392, and $358 \mathrm{~kg}$, respectively. These production levels were slightly above the national averages for the breeds. The SR cows were in a selection experiment. They were bred for either high $(n=148)$ or low $(n=159)$ fat content in their milk, while maintaining the same total energy production.

Before 1992, the experimental herd was kept on a farm with tie-stall housing (Kungsängen). The current research farm (Jälla) has a free-stall barn $(\mathrm{n}=50)$ and a tie-stall barn $(\mathrm{n}=50)$. On both farms cows were kept in maternity pens at the time of calving.
Table 1. Number of cases and lactational incidence risk (LIR) of clinical mastitis in primiparous and multiparous cows of different breed classes

\begin{tabular}{|c|c|c|c|c|}
\hline \multirow[b]{2}{*}{ Breed class } & \multicolumn{2}{|c|}{$\begin{array}{l}\text { Primiparous } \\
\text { cows }\end{array}$} & \multicolumn{2}{|c|}{$\begin{array}{l}\text { Multiparous } \\
\text { cows }\end{array}$} \\
\hline & $\begin{array}{c}\text { Cases } \\
\text { (n) }\end{array}$ & $\begin{array}{c}\mathrm{LIR} \\
(\%)\end{array}$ & $\begin{array}{c}\text { Cases } \\
\text { (n) }\end{array}$ & $\begin{array}{c}\text { LIR } \\
(\%)\end{array}$ \\
\hline Swedish Holstein & 49 & 26.1 & 86 & 34.7 \\
\hline Swedish Red, high-fat line & 18 & 12.2 & 53 & 22.6 \\
\hline Swedish Red, low-fat line & 31 & 19.5 & 61 & 28.4 \\
\hline
\end{tabular}

The cows were fed according to Swedish standards (Spörndly, 1999). In the first 16 wk of lactation, cows were fed ad libitum. Thereafter, they were fed a restricted ration based on production level and weight. In the tie-stall barn, cows were fed the total ration individually, whereas in the free-stall barn, only concentrates were fed individually. During the pasture period (May to September), additional concentrates and roughage were supplied.

All cows were milked twice daily and were test milked once a week. The milk samples were analyzed for fat and protein content according to standard procedures.

\section{Disease Data}

Cases of CM were detected, by the milkers, by presence of abnormal milk in the first milk streams or by signs of inflammation in one or more quarters. All cases were diagnosed by a veterinarian; however, not all cases were treated, depending on the stage in lactation at which the cow developed the disease as well as possible designation for culling. The number of cases and the lactational incidence risk (lactations with at least one case of CM divided by the total number of lactations at risk) of CM in primiparous and multiparous cows of the different breed classes are shown in Table 1.

When a cow was treated with antibiotics the milk was discarded, but the cow was test milked and the milk weighed. Thus, milk records were available for the entire disease period. The affected quarters were sampled and the milk cultured to determine the pathogens present. Additional samples were taken $2 \mathrm{wk}$ after completed treatment.

Milk samples for bacteriological culture were also taken from cows with SCC $>180,000$ cells $/ \mathrm{mL}$ on 2 subsequent test days. Furthermore, milk samples were taken from each quarter by routine in wk 4 of lactation, as well as before the cows were dried. From the fall of 1997, milk samples were also taken in the first week of lactation. From 1993 to 2004, milk samples were taken from 1,560 quarters, and $40 \%$ of the samples had 
Table 2. Pathogens present in culture-positive milk samples $(\mathrm{n}=$ 624) taken from mastitic quarters as well as by routine

\begin{tabular}{lc}
\hline Pathogen & Frequency $(\%)$ \\
\hline Mixed culture & 25 \\
Staphylococcus aureus $^{1}$ & 10 \\
Staphylococcus aureus $^{2}$ & 1 \\
CNS $^{1}$ & 12 \\
CNS $^{2}$ & 6 \\
Streptococcus agalactiae & 0 \\
Streptococcus dysgalactiae & 11 \\
Streptococcus uberis & 7 \\
Other Streptotoccus spp. & 1 \\
Escherichia coli & 16 \\
Klebsiella spp. & 5 \\
Arcanobacterium pyogenes & 3 \\
Other pathogens & 3 \\
\hline
\end{tabular}

${ }^{1}$ Sensitive to penicillin.

${ }^{2}$ Resistant to penicillin.

positive cultures. Table 2 shows the pathogens present in the culture-positive milk samples. Pathogen-specific analyses could not be performed because of the limited number of clinical cases.

To relate the test-day yields to the time of clinical diagnosis, a mastitis index was created according to Gröhn et al. (2004) and Wilson et al. (2004). The index was a categorical variable for time intervals before and after the diagnosis, modeling the time of every test milking relative to the day of CM (Table 3). Separate index categories were created for the 4 wk preceding diagnosis and the $10 \mathrm{wk}$ following diagnosis. All test days occurring earlier than 4 wk before diagnosis were summarized into one category and all test days occurring later than $10 \mathrm{wk}$ after diagnosis were grouped into another category. Nonmastitic cows constituted a

Table 3. Description of the mastitis index

\begin{tabular}{lcc}
\hline & \multicolumn{2}{c}{$\begin{array}{c}\text { Test day relative } \\
\text { to day of diagnosis }\end{array}$} \\
\cline { 2 - 3 } $\begin{array}{l}\text { Mastitis } \\
\text { index }\end{array}$ & Day & Week \\
\hline 1 & $<-28$ & $<-4$ \\
2 & -28 to -22 & -4 \\
3 & -21 to -15 & -3 \\
4 & -14 to -8 & -2 \\
5 & -7 to -1 & -1 \\
$6^{1}$ & 0 to 7 & 1 \\
7 & 8 to 14 & 2 \\
8 & 15 to 21 & 3 \\
9 & 22 to 28 & 4 \\
10 & 29 to 35 & 5 \\
11 & 36 to 42 & 6 \\
12 & 43 to 49 & 7 \\
13 & 50 to 56 & 8 \\
14 & 57 to 63 & 9 \\
15 & 64 to 70 & 10 \\
16 & $>70$ & $>10$ \\
17 & Nonmastitic & Nonmastitic \\
\hline
\end{tabular}

${ }^{1}$ Index 6 includes the day that clinical mastitis is diagnosed. separate index category and were used as a reference for the yield level of healthy cows.

Some other clinical disorders, which were expected to influence milk yield and predispose to CM, were included in the analyses to adjust for their effects as confounders. Due to the relatively low frequencies involved they were grouped into 4 complexes of disorders as follows:

1. Calving disorders: dystocia (assistance by 2 persons or by a veterinarian) or stillbirth (calf born dead or dead within $24 \mathrm{~h}$ of birth).

2. Reproductive disorders: retained placenta ( $>24 \mathrm{~h})$, cystic ovarian disease ( $>40 \mathrm{~d}$ postpartum), metritis, endometritis, pyometra, or anestrus.

3. Metabolic disorders: milk fever, ketosis, or displaced abomasum.

4. Claw disorders: interdigital phlegmon, interdigital dermatitis, heel horn erosion, sole hemorrhages, sole ulcer, claw abscess, or laminitis.

Dystocia, stillbirth, and retained placenta were diagnosed by the farm personnel. Claw disorders were diagnosed by either a veterinarian or a professional hoof trimmer. Other disorders were diagnosed by a veterinarian.

Indices were created for the 4 complexes of disorders. Due to limitations of the data, these indices were not as detailed as the mastitis index. For reproductive disorders, metabolic disorders, and claw disorders the indices had 5 categories: the first 4 were test-day yields measured more than 1 mo before diagnosis, less than 1 mo before diagnosis, less than 1 mo after diagnosis, and in the period thereafter. Cows that had not contracted any of the disorders included in a complex were given a fifth category. Because calving disorders obviously only appeared early in lactation, that index had 3 categories; within 1 mo after diagnosis, more than 1 mo after diagnosis and not affected.

\section{Statistical Methods}

We analyzed the first lactational incidence of CM, regardless of etiology $(n=298)$. Cases that occurred before first calving or in a dry period were thus excluded from the study.

The effects of CM on the daily milk, fat, and protein production were estimated using a mixed linear model in the MIXED procedure of SAS (SAS Institute, 2001). The data set contained repeated measurements of testday yields within lactations. The correlations between test days were accounted for by specifying a correlation structure among the residuals. The first-order autoregressive covariance structure was used. It has pre- 
viously been shown to be appropriate for this type of data (Rajala and Gröhn, 1998; Gröhn et al., 1999; Santos et al., 2004; Wilson et al., 2004). The autoregressive covariance structure assumes a constant variance of measurements and declining correlations between measures as the time interval between them increases. Specifying lactation nested within cow and breed as a subject effect in the repeated-statement in the model for multiparous cows indicated that test-days were correlated within the lactations of cows.

The maximum lactation length was set to $305 \mathrm{~d}$. The proportion of lactations with short duration (last testday occurring earlier than 300 DIM) was 46.6 and $62.6 \%$ in primiparous and multiparous cows, respectively. The median DIM when the last test-day occurred was 300 in primiparous cows and 295 in multiparous cows. Due to different shapes of their lactation curves, primiparous and multiparous cows were analyzed separately (494 and 698 lactations, 17,039 and 21,496 test days, respectively). For multiparous cows the following model was used:

$$
\begin{gathered}
\mathrm{Y}=\text { mastitis index } \times \text { lactational stage }+ \text { breed } \\
+ \text { parity }+ \text { reproductive status }+ \text { calving year/season } \\
+ \text { index for calving disorders } \\
+ \text { index for reproductive disorders } \\
+ \text { index for metabolic disorders } \\
+ \text { index for claw disorders }+\varepsilon
\end{gathered}
$$

where $\mathrm{Y}$ was the milk, fat, or protein production at each test-day. The lactations were divided into 19 stages. Thus, milk records collected within the first $8 \mathrm{wk}$ of lactation were grouped into weekly intervals; records from wk 9 to wk 16 were grouped into 2 -wk periods, and records taken later than $17 \mathrm{wk}$ after calving were grouped into 4 -wk periods. The mastitis index was defined as above. Breed had 3 levels: SR low-fat line, SR high-fat line, and SH. Parity was defined as 2 or $\geq 3$. Reproductive status indicated whether the cow was pregnant on the test day. We distinguished between 3 calving seasons: January to April, May to August, and September to December. Year and season of calving were pooled and analyzed as a combined variable comprising 50 classes. The indices for other disorders were as defined above. Interactions of biological interest were tested in the preliminary analyses, but were excluded from the final models as they were found to be nonsignificant.

\begin{tabular}{|c|c|c|c|c|}
\hline \multirow[b]{2}{*}{ Disorder } & \multicolumn{2}{|c|}{$\begin{array}{c}\text { Primiparous } \\
\text { cows }\end{array}$} & \multicolumn{2}{|c|}{$\begin{array}{l}\text { Multiparous } \\
\text { cows }\end{array}$} \\
\hline & $\begin{array}{c}\text { Cases } \\
(\mathrm{n})\end{array}$ & $\begin{array}{l}\text { LIR } \\
(\%)\end{array}$ & $\begin{array}{c}\text { Cases } \\
(\mathrm{n})\end{array}$ & $\begin{array}{l}\text { LIR } \\
(\%) \\
\end{array}$ \\
\hline Clinical mastitis & 98 & 19.8 & 200 & 28.7 \\
\hline Calving disorders & 35 & 7.1 & 39 & 5.6 \\
\hline Reproductive disorders & 52 & 10.5 & 98 & 14.0 \\
\hline Metabolic disorders & 4 & 0.8 & 108 & 15.5 \\
\hline Claw disorders & 72 & 14.6 & 71 & 10.2 \\
\hline
\end{tabular}

In the model for primiparous cows, the index for metabolic disorders was excluded due to there being very few cases, and parity was excluded for obvious reasons.
Table 4. Lactational incidence risk (LIR) of disorders in primiparous and multiparous cows

The residuals were tested for normality using a $\mathrm{Q}-\mathrm{Q}$ plot, and were judged as being close to the normal distribution.

\section{Estimation of 305-d Yields}

To compare the long-term yield losses associated with $\mathrm{CM}$ occurring in different stages of lactation, estimates of the 305-d yields for cows diagnosed with CM in wk 1 to 44 of lactation were calculated and compared with the yields of nonmastitic cows.

Least squares means (LSM) of the interaction between lactational stage and mastitis index were used as estimates of the daily production of milk, fat, and protein in a certain week of lactation at a certain time with respect to diagnosis. The LSM comprising the complete lactation of each group of cows (healthy and diseased in a specified week) were then multiplied by 7 to give the weekly yields, and thereafter summed, resulting in estimates for the 305-d yields.

Not all combinations of lactational stage and mastitis index were available from the analyses, because in some weeks of lactation no case of CM occurred. When an LSM was missing for a combination in the middle of a lactation, the estimated daily yield during that week was calculated as the mean value of the LSM from the week before and the week after the missing value. If the missing LSM was from the beginning or the end of lactation, and hence no estimate from the week before or after was available, the mean value of the LSM from the corresponding week of lactation in cows that had developed CM 1 wk earlier and 1 wk later was used.

\section{RESULTS}

The lactational incidence risks of the disorders are presented in Table 4. Clinical mastitis was more frequent in multiparous than in primiparous cows. Firstparity cows developed CM earlier in lactation than older cows: the median time of diagnosis was d 11 (third quartile $=100$ ) and $d 55$ (third quartile $=127$ ), respectively. The production of primiparous cows peaked at 
wk 8, whereas multiparous cows reached peak production at wk 7 . Thus, primiparous cows usually developed $\mathrm{CM}$ before peak yield and multiparous cows more commonly developed CM after peak yield. As this study focused on the effects of $\mathrm{CM}$ on production, no further attention will be paid to the impact of the complexes of disorders.

The interaction between mastitis index and lactational stage was highly significant in all models. Thus, the magnitude of the yield losses associated with $\mathrm{CM}$ depended on the week of lactation in which the cow was diseased. Lactation curves for nonmastitic cows and cows that were diagnosed with CM in early lactation, at peak yield, in mid lactation and in late lactation were constructed based on LSM from the interaction between mastitis index and lactational stage (Figure 1). To illustrate the weeks of diagnosis in which most data were available, lactation curves for cows diagnosed in different weeks were plotted for primiparous and multiparous cows diseased in late lactation. The stairlike shape of the lactation curves is due to the grouping of weeks into lactation stages after wk 8.

The production levels of cows developing CM in early lactation tended to be below those of cows that were nonmastitic throughout the entire lactation. This seemed to be the case in primiparous as well as in multiparous cows. Primiparous cows developing $\mathrm{CM}$ at the time of peak yield appeared to produce milk at the same level as nonmastitic cows during the first weeks of lactation, but when they were diseased in mid or late lactation their initial yields tended to be higher than those of nonmastitic cows. Multiparous cows that developed CM at peak yield, in mid lactation, or in late lactation all seemed to produce more milk than nonmastitic cows before becoming diseased. The difference between the initial yield of mastitic cows diseased in mid or late lactation and nonmastitic cows appeared to be greater in multiparous cows. After cows had been diagnosed with CM, no matter when in lactation, their milk yield tended to be suppressed throughout the rest of lactation.

\section{Short-Term Losses}

The pattern and extent of the short-term losses associated with CM depended on the lactational stage of the cow when diagnosed with the disease. Figure 2 shows the patterns of short-term losses when CM occurred in selected weeks of lactation. Milk yield tended to decline 2 to $4 \mathrm{wk}$ before diagnosis. The drop in milk yield was, however, either not significant or significant only in the week preceding diagnosis. A drop in production seemed to occur $4 \mathrm{wk}$ (or more) before diagnosis when cows developed CM around peak yield. When cows were diseased in mid lactation the drop seemed to occur 3 wk before diagnosis and when cows developed $\mathrm{CM}$ in late lactation it seemed to start $2 \mathrm{wk}$ before diagnosis.

At the time of clinical onset, the reduction in milk yield in mastitic primiparous cows was about $5 \mathrm{~kg}$, irrespective of when in lactation the cow was diseased. In multiparous cows there was a trend toward increased daily milk loss the earlier in lactation that the cow developed CM.

Primiparous and multiparous cows diseased in the first week of lactation did not reach the yield level of nonmastitic cows in the 10 -wk period following diagnosis. Cows that were diagnosed with $\mathrm{CM}$ in wk 8 of lactation produced significantly less than nonmastitic cows for some weeks after clinical onset. When diseased later in lactation, cows reached the production level of nonmastitic cows approximately $5 \mathrm{wk}$ after diagnosis, but still produced less than they did $3 \mathrm{wk}$ before diagnosis. The differences between daily milk yields of mastitic cows diseased in late lactation and daily milk yields of nonmastitic cows were, however, not significant in the 10-wk period following diagnosis, except for multiparous cows showing a significantly increased milk yield 6 wk after clinical onset.

\section{Losses over $305 d$}

The extrapolated 305-d yields (based on LSM) of nonmastitic primiparous cows (396 lactations) were 7,675 $\mathrm{kg}$ of milk, $330 \mathrm{~kg}$ of fat, and $259 \mathrm{~kg}$ of protein. The corresponding figures in multiparous cows (498 lactations) were $7,862 \mathrm{~kg}$ of milk, $337 \mathrm{~kg}$ of fat, and $253 \mathrm{~kg}$ of protein. The 305-d yields of mastitic cows diagnosed in different weeks of lactation, expressed as a percentage of the yields of nonmastitic cows, are shown in Figure 3.

Mastitic primiparous cows seemed to have lower 305d milk production compared with their nonmastitic herdmates, except for cows diagnosed at the very end of lactation. The lactational protein yield showed a similar pattern. Primiparous cows that became diseased during the first half of lactation appeared to produce less fat on a 305-d basis than nonmastitic primiparous cows, whereas primiparous cows diagnosed with CM later in lactation seemed to have a higher protein yield. The milk loss varied from 0 to $705 \mathrm{~kg}$, corresponding to 0 to $9 \%$ of the 305 -d yield. The largest milk loss was found in primiparous cows diseased in wk 6 of lactation. Mastitic primiparous cows had a reduced 305-d fat yield of 0 to $27 \mathrm{~kg}$ ( 0 to $8 \%$ of the total yield), with the largest loss occurring in primiparous cows diseased in wk 5 or 6 of lactation. The reduction in 305-d protein yield varied 
Primiparous cows

CM in wk 1
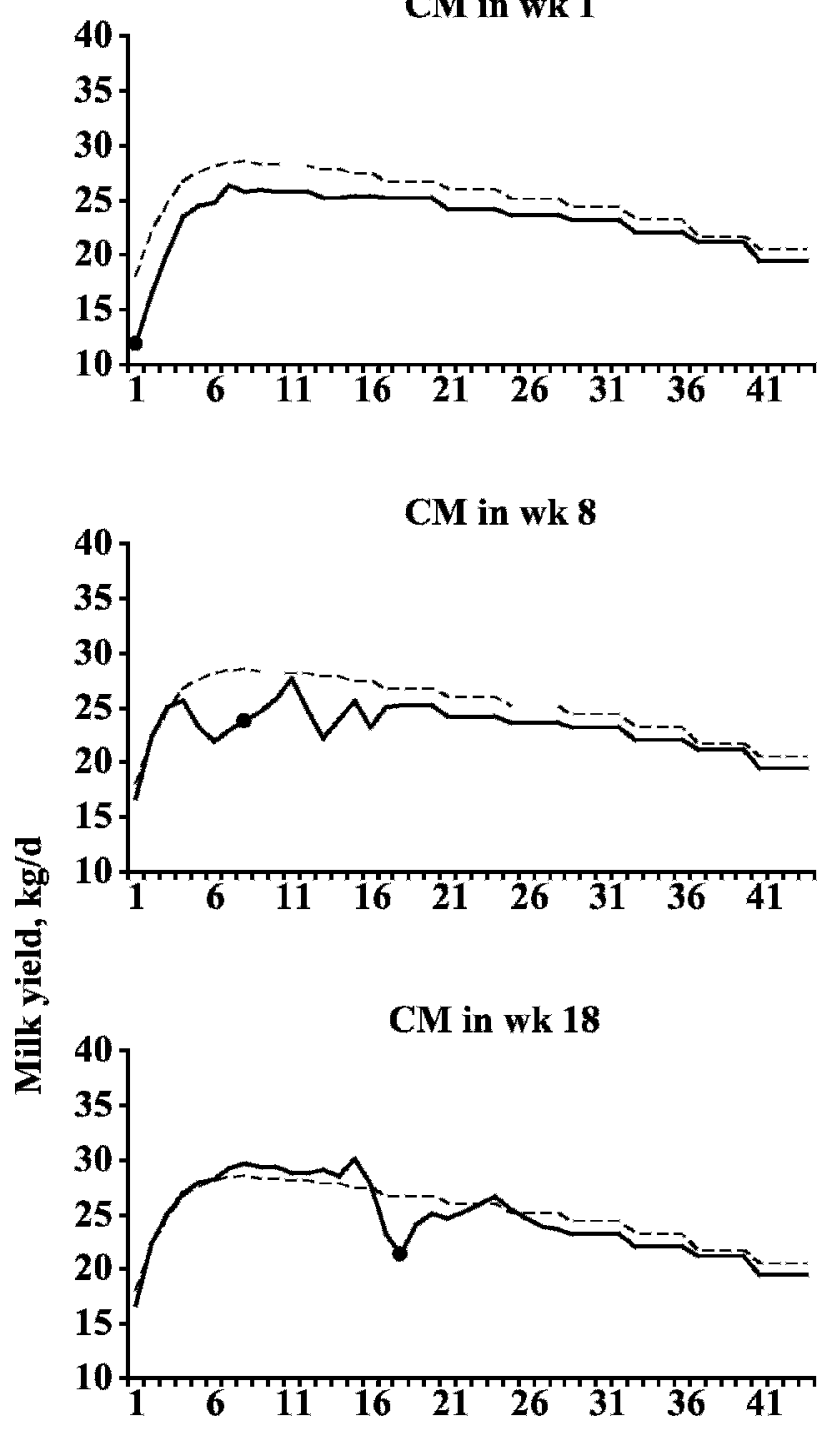

CM in wk 36

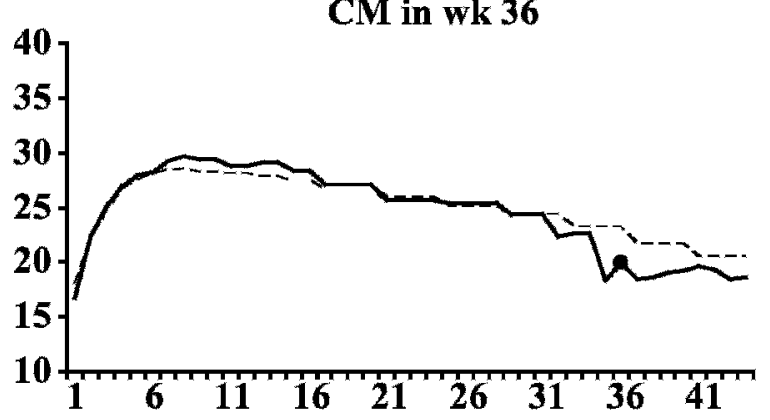

Multiparous cows

CM in wk 1
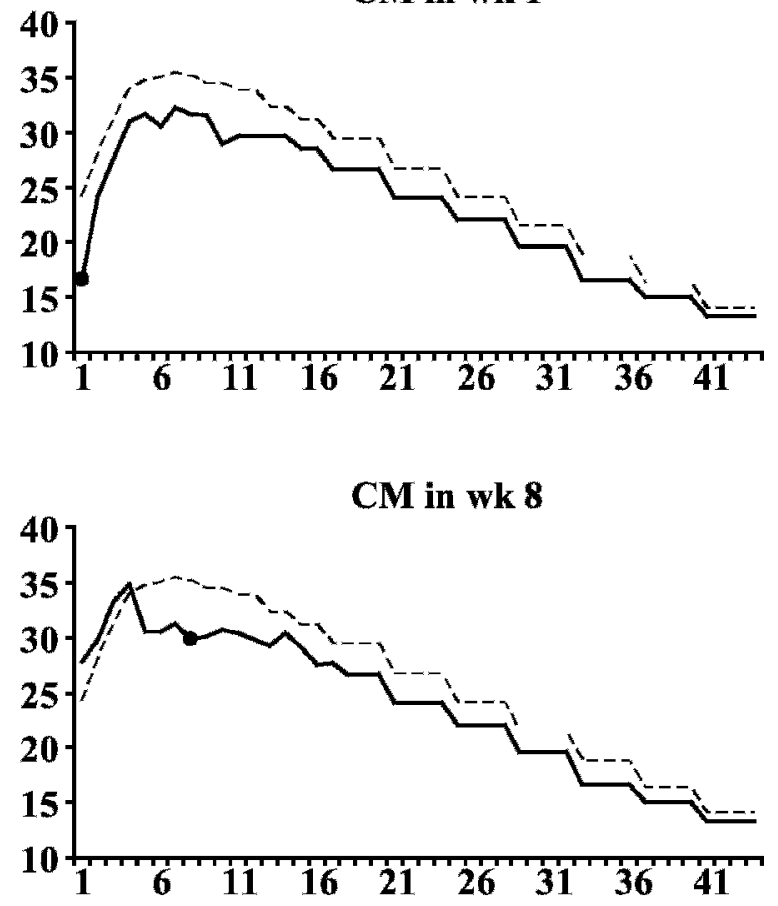

CM in wk 18

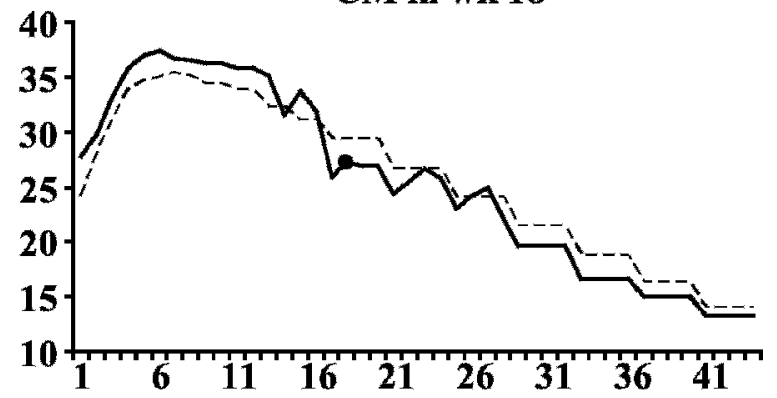

Week of lactation

Figure 1. Lactation curves (based on least squares means) for primiparous and multiparous cows. The dotted lines represent nonmastitic cows and the solid lines represent cows with clinical mastitis (CM) in various weeks of lactation; $\bullet$ week of diagnosis. 


\section{Primiparous cows}

$\mathrm{CM}$ in wk $1(\mathrm{SE}=0.59-1.76)$

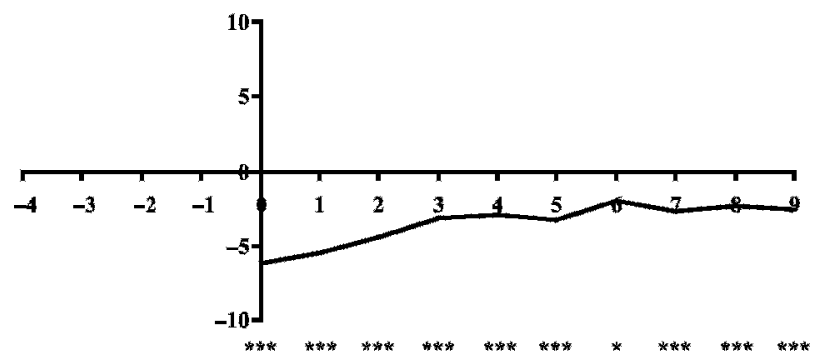

CM in wk $8(\mathrm{SE}=\mathbf{0 . 5 9 - 3 . 4 3})$

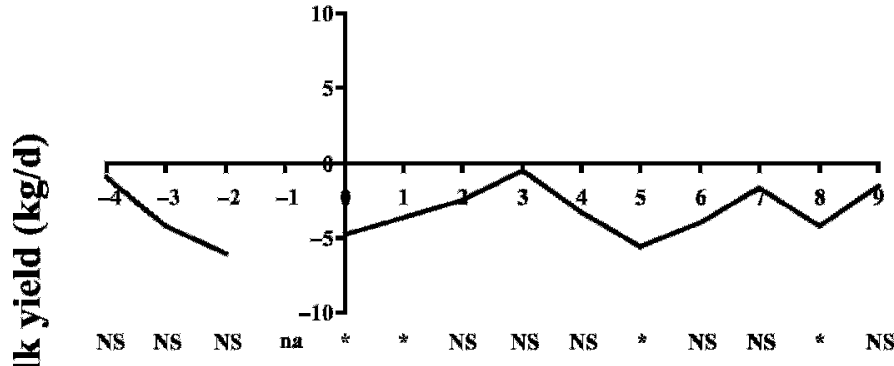

$\mathrm{CM}$ in wk $18(\mathrm{SE}=0.59-2.50)$

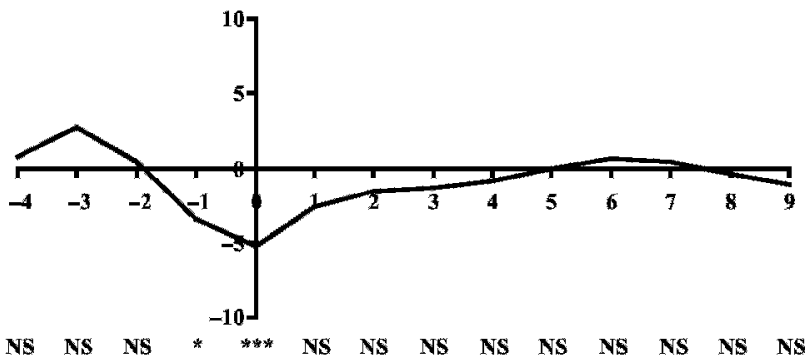

CM in wk $36(\mathrm{SE}=0.87-3.97)$

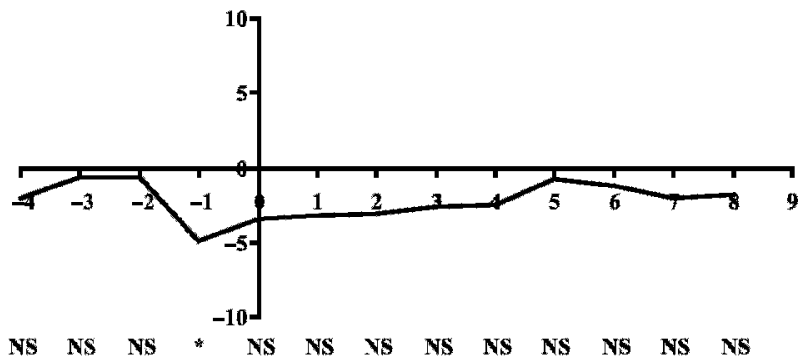

Multiparous cows

$\mathrm{CM}$ in wk $1(\mathrm{SE}=0.47-2.06)$

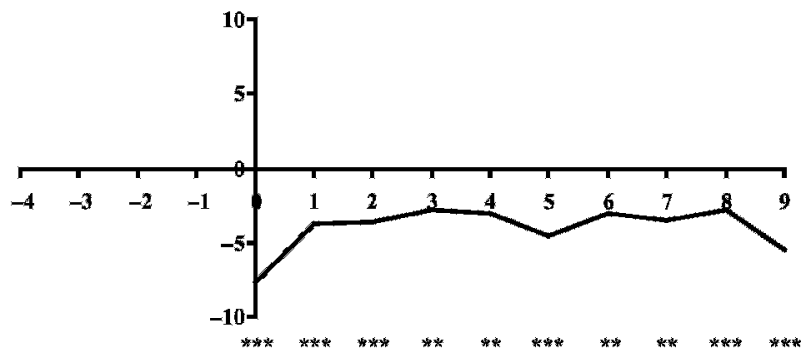

$\mathrm{CM}$ in wk $8(\mathrm{SE}=0.47-3.35)$

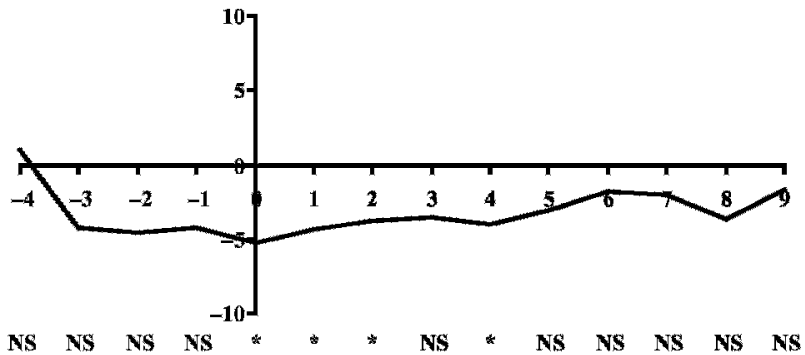

CM in wk $18(\mathrm{SE}=0.47-1.86)$

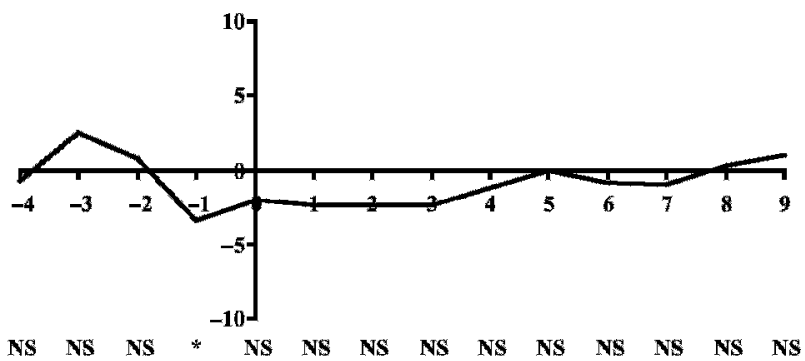

$\mathrm{CM}$ in wk $38(\mathrm{SE}=0.61-4.09)$

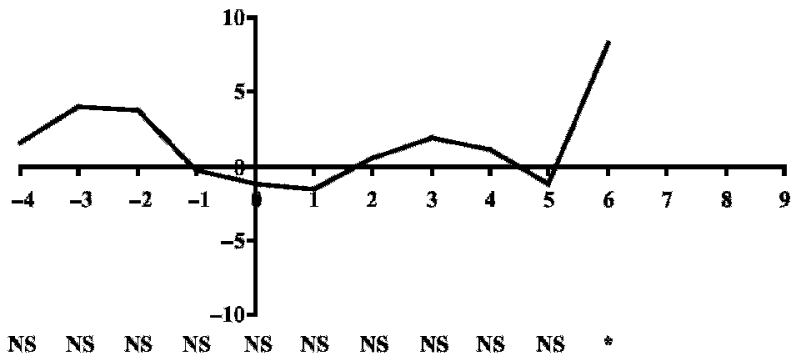

\section{Week relative to diagnosis}

Figure 2. Deviations (least squares means, $\mathrm{kg}$ of milk/d) from the daily milk yield of nonmastitic cows in the weeks before and after diagnosis, in primiparous and multiparous cows that were diagnosed with clinical mastitis (CM) in different weeks of lactation. The range of standard errors (SE) of the yield estimates of mastitic cows is also shown. ${ }^{*} P<0.05$; $* * P<0.01$; $* * * P<0.001$; NS $=$ nonsignificant; na $=$ not available. 
Primiparous cows

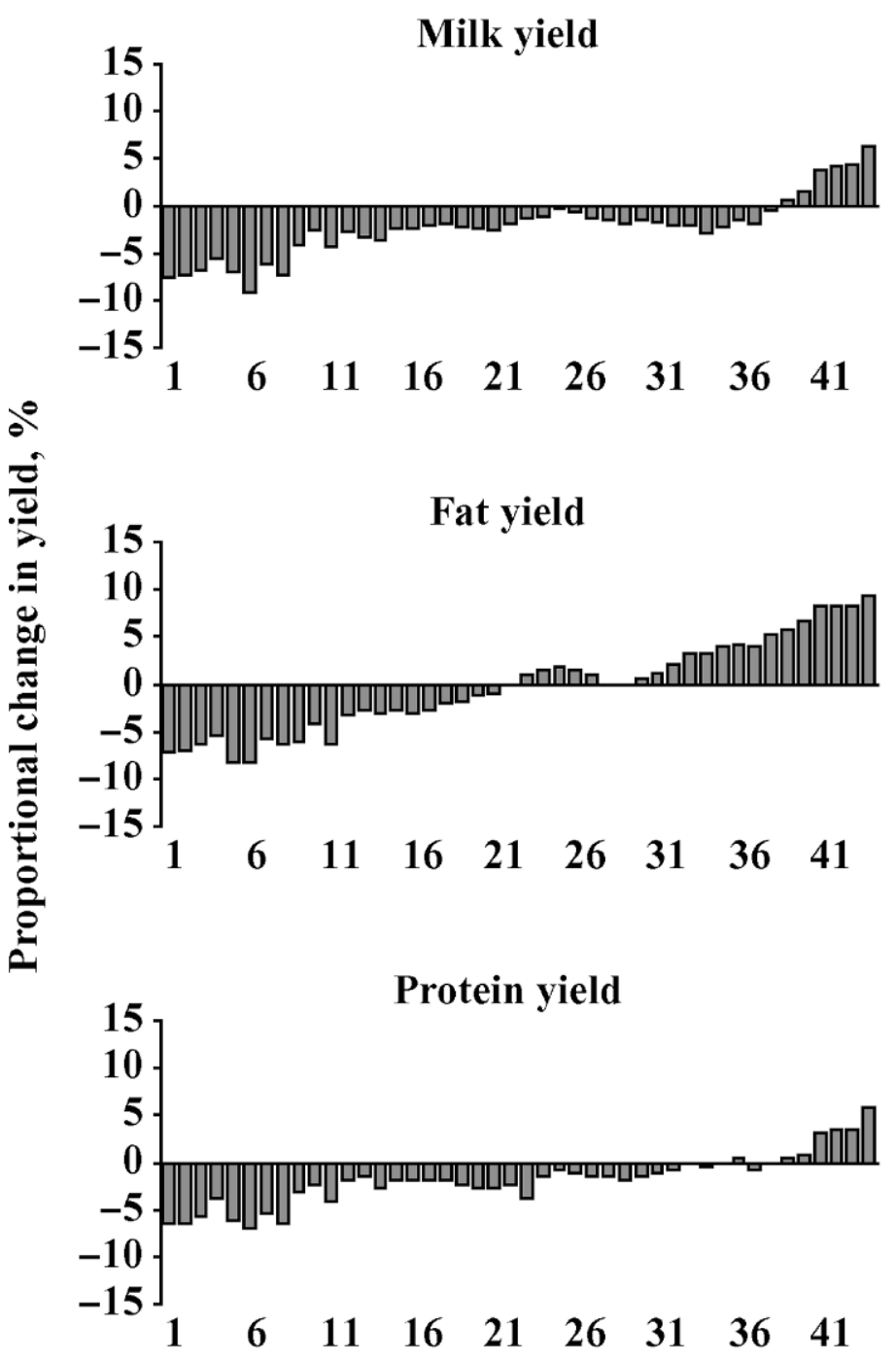

Multiparous cows

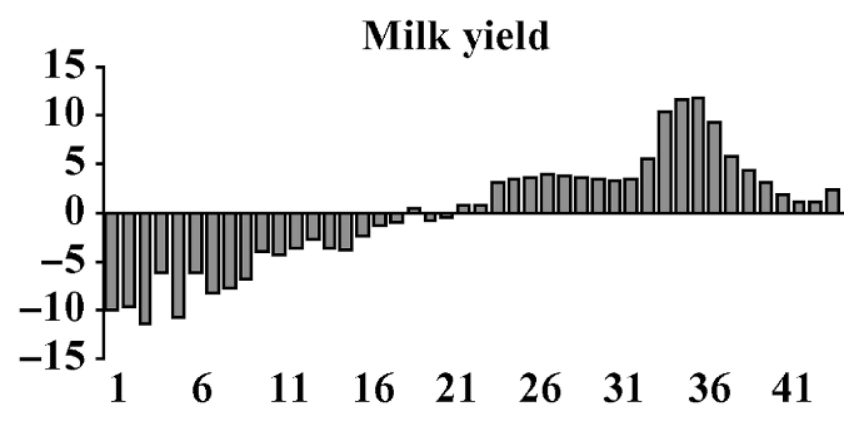

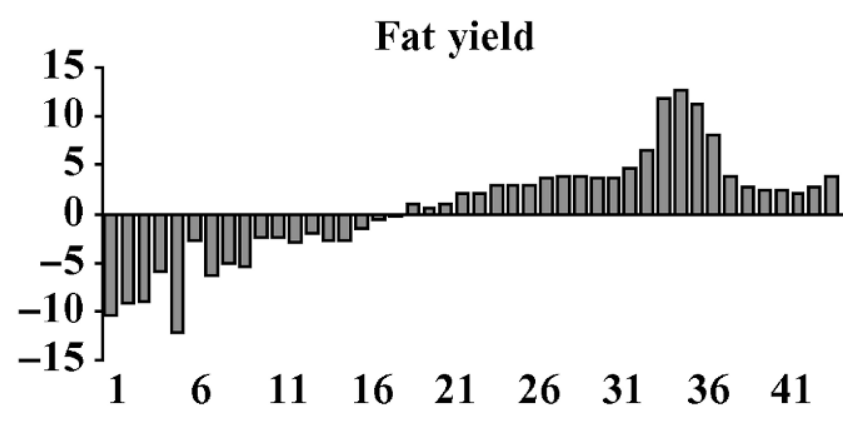

\section{Week of lactation}

Figure 3. Proportional change in 305-d milk, fat, and protein yields (based on least squares means) in primiparous and multiparous cows diagnosed with clinical mastitis in different weeks of lactation relative to the corresponding yields of nonmastitic cows (shown on the $\mathrm{y}$-axis). The $\mathrm{x}$-axis shows the week of lactation at the time of diagnosis.

from 0 to $18 \mathrm{~kg}$ ( 0 to $7 \%$ of the total yield), with primiparous cows with $\mathrm{CM}$ in wk 6 showing the largest losses.

The 305-d milk, fat, and protein yields of mastitic multiparous cows were more uniform than those of primiparous cows. Multiparous cows diagnosed with CM in the first half of lactation tended to perform below nonmastitic multiparous cows, whereas cows diagnosed with CM in the latter part of lactation had higher 305$\mathrm{d}$ yields. The most severe milk loss was found when multiparous cows were diseased in wk 3 . The magni- tude of the yield loss varied from 0 to $902 \mathrm{~kg}$, or 0 to $11 \%$ of the 305-d milk yield. The reduction in 305-d fat yield was 0 to $41 \mathrm{~kg}$ ( 0 to $12 \%$ of the total yield). Multiparous cows diseased in wk 5 experienced the most extensive loss of fat production. The protein yield was decreased by 0 to $27 \mathrm{~kg}$ ( 0 to $11 \%$ of the total yield) in mastitic multiparous cows, with the largest reduction occurring when diseased in wk 3 .

Multiparous cows diseased before wk 22 appeared to have lower 305-d milk yields than nonmastitic multipa- 
rous cows. In primiparous cows, mastitic cows diseased in wk 1 to 38 tended to produce less than nonmastitic cows on a 305-d basis. The actual milk loss as well as the proportional milk loss during the weeks when both groups produced less than nonmastitic cows were smaller in primiparous cows.

\section{DISCUSSION}

\section{Declining Daily Milk Yield Weeks Before CM}

The onset of CM seemed to be associated with a drop in milk yield 2 to 4 wk before diagnosis, confirming results by Lucey et al. (1986) and Rajala-Schultz et al. (1999). Other studies have found the reduction in milk yield to occur later, during the week before diagnosis or during the week of diagnosis (Østergaard and Gröhn, 1999; Bareille et al., 2003; Wilson et al., 2004). A decline in milk yield in the weeks before clinical onset is probably due to the disease being subclinical for some time before the clinical signs are manifested. Gröhn et al. (2004) found the start of the reduction in milk yield, in relation to clinical onset, to be dependent on the pathogen causing the disease. They used the yield level of cows not affected by the specific pathogen as the reference. When CM in primiparous cows was caused by Staphylococcus aureus, Staphylococcus spp., or "no pathogen isolated," milk yield began to drop several weeks before clinical onset. In multiparous cows, daily milk yield was reduced in the week before diagnosis when CM was caused by Streptococcus spp., Staph. aureus, or Klebsiella spp., whereas when CM was caused by Arcanobacterium pyogenes, the drop could be observed 4 wk before diagnosis. When CM was caused by Escherichia coli, milk yield dropped in the week following clinical onset. Thus, different pathogens may give rise to longer or shorter periods of subclinical infection before the outbreak of CM. Variation between studies in how long before CM the drop occurs could therefore be explained to some extent by different pathogen frequencies in the studied herds. The discrepancy between studies could, of course, also be the result of different criteria for CM being applied.

In multiparous cows, the size of the fluctuations in daily milk yield associated with clinical diagnosis tended to depend on the stage of lactation in which the cow was diseased, in accordance with the results of Lucey et al. (1986) and Rajala-Schultz et al. (1999). Hortet and Seegers (1998) concluded that short-term losses were more severe in cows diseased in early lactation than in cows diseased in mid or late lactation. We observed the same trend, which was particularly pronounced in multiparous cows. At the time of clinical onset, we found that mastitic multiparous cows produced 1 to $8 \mathrm{~kg}$ less milk per day than nonmastitic multiparous cows. Thus, the fluctuations were larger in our study than they were in previous studies, which demonstrated daily losses of less than 1 to $2.5 \mathrm{~kg}$ (Lucey et al., 1986; Rajala-Schultz et al., 1999).

Dohoo and Martin (1984) and Lucey et al. (1986) found that treatment caused a boost in production; subsequently, in mastitic cows, milk yield equaled or exceeded that of nonmastitic cows. This phenomenon was generally not observed in our study, with the exception of the finding that multiparous cows diseased in late lactation had an increased milk yield 6 wk following clinical onset. This result was likely due to uncertainty of the estimate. Cows diseased before or at peak yield did not reach the yield level of nonmastitic cows in the 10 -wk period after diagnosis, indicating that CM caused production losses for an extensive period following clinical onset. This was in accordance with Bartlett et al. (1991), who showed that cows experienced an immediate drop in production when diagnosed with $\mathrm{CM}$ and had a suppressed milk yield throughout the $60 \mathrm{~d}$ following clinical onset.

\section{Substantial Reduction in 305-d Milk Yield}

The effects on production were most severe in cows developing $\mathrm{CM}$ in early lactation, confirming results from previous studies (Bartlett et al., 1991; Hortet and Seegers, 1998; Rajala-Schultz et al., 1999; Santos et al., 2004). Interestingly, Wilson et al. (2004) found that the production of multiparous cows was more affected when they developed CM before peak yield, whereas primiparous cows were most affected when diseased between peak yield and 120 DIM. In our study, primiparous as well as multiparous cows were most affected when CM occurred before peak yield. This was probably due in part to CM causing more severe losses in early lactation. It was also, we believe, the result of CM being experienced over a longer period when developed in early lactation, as Lescourret and Coulon (1994) suggest.

After being diagnosed with CM, cows produced less milk than their nonmastitic herdmates throughout the rest of the lactation; this was in accordance with Wilson et al. (2004). Bareille et al. (2003) found that mastitic cows suffered from yield losses for a period of $140 \mathrm{~d}$ following diagnosis. In Gröhn et al. (2004), mastitic cows did not return to their premastitic milk yield.

The detrimental effect of CM on lactational milk yield has been shown by several studies (Hortet and Seegers, 1998; Rajala-Schultz et al., 1999; Wilson et al., 2004). Comparisons of the actual milk loss between studies are difficult to make. This is partly because there is considerable variation in the data collected (e.g., with regard to period of collection, breed, yield level of cows, country, and whether the data are from a field study 
or relate to a research herd), but it is also the outcome of differences in the analytical methods used. The purpose of comparing our estimates with those attained in previous studies was mainly to validate the magnitude of the losses. The estimated 305-d milk losses in primiparous and multiparous cows of 0 to $9 \%$ and 0 to $11 \%$, respectively, correspond relatively well with previous studies (Hortet and Seegers, 1998; Rajala-Schultz et al., 1999; Wilson et al., 2004). The outlying values were slightly more extreme than those found by others, although these losses occurred only for cows diseased in specific weeks of lactation. Previous studies either did not account for when, during lactation, cows were diseased or used crudely defined periods of lactation. By not distinguishing between cases occurring in the different weeks of lactation, these studies probably ensured that the most severe yield losses were diluted by milder losses in other weeks. The size of the extensive yield losses found in our study can therefore be regarded as reasonable.

\section{Milk, Fat, and Protein Production Are Equally Affected}

The losses of fat and protein were of the same relative magnitude as the milk loss, which is supported by Hortet and Seegers (1998) and Santos et al. (2004). Thus, the effect of CM on fat and protein yield seemed to be caused by reduced milk production and not by changes in the fat and protein content of the milk.

\section{High Milk Production: A Risk Factor for CM}

In our study, as well as in previous work (Lucey and Rowlands, 1984; Østergaard and Gröhn, 1999; Gröhn et al., 2004), the incidence of CM was higher in multiparous cows than in the lower producing primiparous cows. Moreover, milk loss due to CM has been found to be greater in multiparous cows (Bartlett et al., 1991; Hortet and Seegers, 1998; Østergaard and Gröhn, 1999). Within parity groups, mastitic cows have been shown to have a higher production level than nonmastitic cows (Rajala-Schultz et al., 1999; Gröhn et al., 2004; Wilson et al., 2004). We observed the same trend, and, like Wilson et al. (2004), found it especially pronounced in multiparous cows. Furthermore, unfavorable genetic correlations have been found between milk yield and CM (Bunch et al., 1984; Emanuelson et al., 1988). Thus, it can be concluded that high milk yield is a risk factor for CM, supporting the results of BigrasPoulin et al. (1990), Rajala and Gröhn (1998), Østergaard and Gröhn (1999), and Wilson et al. (2004).

The seemingly higher 305-d yields in mastitic cows affected in mid or late lactation were most certainly a consequence of mastitic cows producing above the level of nonmastitic cows to such an extent that the cumulative 305-d yields were higher, even though the cows had suffered from CM. These cows would probably have been even more superior to their nonmastitic herdmates had they not developed CM, and it is most likely that the estimated losses would have been larger still if we had corrected for the production potential of the cows in the models.

\section{Sources of Possible Bias}

Studying a research herd inevitably imposes a certain bias on the data. Closer surveillance of the animals leads to more cases than normal receiving treatment. This is also shown by the high lactational incidence of CM in our study: 19.8 and $28.7 \%$ in primiparous and multiparous cows, respectively, compared with incidences of 9.1 and 13.2 to $24.3 \%$ in cows enrolled in the milk-recording scheme in 2004-2005 (Swedish Dairy Association, 2005). Some of the reported cases were probably milder than those reported by practicing veterinarians, which might have influenced the size of the yield estimates.

There are other possible sources of bias in our data. By only including the first lactational incidence of CM, all losses were attributed to just one case. Thus, in lactations with recurrent cases, the loss assigned to the first case will have been overestimated. In addition, nonmastitic cows are usually poorer producers. Therefore, using the yield of nonmastitic cows as a reference for the production level in healthy cows certainly results in an underestimation of the actual losses associated with CM. Finally, our estimated losses are valid on a 305-d basis, assuming that mastitic cows have complete lactations. A consequence of $\mathrm{CM}$ can be forced drying off and therefore shortened lactation. When this is the case, the yield losses will probably be even more severe than those reported here.

\section{Implications}

The results of this study are of practical interest to dairy farmers, showing that preventative measures should be focused on reducing the frequency of $\mathrm{CM}$ between calving and peak yield, because this is the period when the majority of cases occur and when yield losses are the most extensive.

The possibilities of utilizing the fact that daily milk yield starts to drop roughly $3 \mathrm{wk}$ before diagnosis should be investigated. It is likely that the detrimental effects of CM can be reduced if the disease is diagnosed and treated when the drop in production first occurs instead of when the clinical signs are manifested. 


\section{CONCLUSIONS}

This study used state-of-the-art methodology to estimate the yield losses associated with CM. By including the interaction between mastitis index and lactational stage in the models we were able to conclude that the week of lactation at clinical onset determines the magnitude of milk, fat, and protein losses arising from CM. Mastitic primiparous cows produced 0 to $9 \%$ less milk, 0 to $8 \%$ less fat, and 0 to $7 \%$ less protein on a 305$\mathrm{d}$ basis than did nonmastitic primiparous cows. The greatest losses occurred when primiparous cows developed CM in wk 6. Mastitic multiparous cows had reduced 305 -d yields of 0 to $11 \%$ milk, 0 to $12 \%$ fat, and 0 to $11 \%$ protein. Multiparous cows experienced the most extensive losses when diseased in wk 3 . The losses of fat and protein were of the same relative magnitude as the milk loss. Cows that developed CM had a higher initial production level than nonmastitic cows. A drop in daily milk yield was observed 2 to 4 wk before diagnosis. After a case of CM, milk yield tended to be suppressed throughout the rest of the lactation.

\section{ACKNOWLEDGMENTS}

The Swedish Farmers' Foundation for Agricultural Research is acknowledged for financial support. We also thank the staff at Jälla for providing the data for the study.

\section{REFERENCES}

Bareille, N., F. Beaudeau, S. Billon, A. Robert, and P. Faverdin. 2003. Effects of health disorders on feed intake and milk production in dairy cows. Livest. Prod. Sci. 83:53-62.

Bartlett, P. C., J. Vanwijk, D. J. Wilson, C. D. Green, G. Y. Miller, G. A. Majewski, and L. E. Heider. 1991. Temporal patterns of lost milk-production following clinical mastitis in a large Michigan Holstein herd. J. Dairy Sci. 74:1561-1572.

Bigras-Poulin, M., A. H. Meek, and S. W. Martin. 1990. Interrelationships among health problems and milk production from consecutive lactations in selected Ontario Holstein cows. Prev. Vet. Med. 8:15-24.

Bunch, K. J., D. J. S. Heneghan, K. G. Hibbitt, and G. J. Rowlands. 1984. Genetic influences on clinical mastitis and its relationship with milk yield, season and stage of lactation. Livest. Prod. Sci. 11:91-104.

Degraves, F. J., and J. Fetrow. 1993. Economics of mastitis and mastitis control. Vet. Clin. North Am. Food Anim. Pract. 9:421-434.

Dohoo, I. R., and S. W. Martin. 1984. Disease, production and culling in Holstein-Friesian cows. IV. Effects of disease on production. Prev. Vet. Med. 2:755-770.

Emanuelson, U., B. Danell, and J. Philipsson. 1988. Genetic parameters for clinical mastitis, somatic cell counts, and milk production estimated by multiple-trait restricted maximum likelihood. J. Dairy Sci. 71:467-476.

Gröhn, Y. T., J. J. McDermott, Y. H. Schukken, J. A. Hertl, and S. W. Eicker. 1999. Analysis of correlated continuous repeated observations: Modelling the effect of ketosis on milk yield in dairy cows. Prev. Vet. Med. 39:137-153.

Gröhn, Y. T., D. J. Wilson, R. N. Gonzalez, J. A. Hertl, H. Schulte, G. Bennett, and Y. H. Schukken. 2004. Effect of pathogen-specific clinical mastitis on milk yield in dairy cows. J. Dairy Sci. 87:3358-3374.

Hortet, P., and H. Seegers. 1998. Loss in milk yield and related composition changes resulting from clinical mastitis in dairy cows. Prev. Vet. Med. 37:1-20.

Lescourret, F., and J. B. Coulon. 1994. Modeling the impact of mastitis on milk production by dairy cows. J. Dairy Sci. 77:2289-2301.

Lucey, S., and G. J. Rowlands. 1984. The association between clinical mastitis and milk yield in dairy cows. Anim. Prod. 39:165-175.

Lucey, S., G. J. Rowlands, and A. M. Russell. 1986. Short-term associations between disease and milk yield of dairy cows. J. Dairy Res. 53:7-15.

Østergaard, S., and Y. T. Gröhn. 1999. Effects of diseases on test day milk yield and body weight of dairy cows from Danish research herds. J. Dairy Sci. 82:1188-1201.

Rajala, P. J., and Y. T. Gröhn. 1998. Effects of dystocia, retained placenta, and metritis on milk yield in dairy cows. J. Dairy Sci. 81:3172-3181.

Rajala-Schultz, P. J., Y. T. Gröhn, C. E. McCulloch, and C. L. Guard. 1999. Effects of clinical mastitis on milk yield in dairy cows. J. Dairy Sci. 82:1213-1220.

Santos, J. E. P., R. L. A. Cerri, M. A. Ballou, G. E. Higginbotham, and J. H. Kirk. 2004. Effect of timing of first clinical mastitis occurrence on lactational and reproductive performance of Holstein dairy cows. Anim. Reprod. Sci. 80:31-45.

SAS Institute. 2001. SAS Version 8.2. SAS Institute Inc., Cary, NC. Spörndly, R., ed. 1999. Fodertabeller för idisslare (Nutrition requirements for ruminants). Publ. No. 247. Swedish Univ. Agric. Sci., Dept. Anim. Nutr. Health, Uppsala, Sweden.

Swedish Dairy Association. 2005. Djurhälsovård (Animal Health Care) 2004/2005. Svensk Mjölk, Eskilstuna, Sweden.

Wilson, D. J., R. N. Gonzalez, J. A. Hertl, H. F. Schulte, G. J. Bennett, Y. H. Schukken, and Y. T. Gröhn. 2004. Effect of clinical mastitis on the lactation curve: A mixed model estimation using daily milk weights. J. Dairy Sci. 87:2073-2084. 